\title{
The Development of Children's Personalities
}

In William Golding's Lord of the Flies

\section{Aisyiyah Hanif Muallim}

\author{
Institut Agama Islam Negeri (IAIN) Palopo
}

Email: aisyiyahmuallim@gmail.com

\section{Abstract}

The aims of the study were to reveal the cause of personality development on children's characters and to elaborate the exertion in eradicating poverty reflects from the novel Lord of the Flies. This study employed descriptive qualitative study with psychoanalytical approach initiated by Sigmund Freud focused on literature as the reflection of real life. The primary data in this study were collected from the novel "Lord of the Flies" by William Golding (1954). The secondary data were taken from the library, internet, and journals, theses, and articles. The research result indicates that the personalities of the children are developed based on the anxiety and defense mechanism as part of psychoanalysis. Other finding is about the reflection of poverty eradication shows in the story. The children's efforts in getting rescued and hunting could be the reflection of escape from poverty.

Keywords: Children, Anxiety, Defence Mechanism

\section{Abstrak}

Tujuan dari penelitian ini adalah untuk mengungkapkan penyebab perkembangan kepribadian pada karakter anak-anak dan untuk menguraikan pengerahan tenaga dalam memberantas kemiskinan tercermin dari novel Lord of the Flies. Penelitian ini menggunakan penelitian kualitatif deskriptif dengan pendekatan psikoanalisis yang diprakarsai oleh Sigmund Freud yang berfokus pada sastra sebagai 
cerminan kehidupan nyata. Data primer dalam penelitian ini dikumpulkan dari novel "Lord of the Flies" oleh William Golding (1954). Data sekunder diambil dari perpustakaan, internet, dan jurnal, tesis, dan artikel. Hasil penelitian menunjukkan bahwa kepribadian anak-anak dikembangkan berdasarkan mekanisme kecemasan dan pertahanan sebagai bagian dari psikoanalisis. Temuan lainnya adalah tentang pantulan pertunjukkan pengentasan kemiskinan dalam cerita. Upaya anak-anak untuk diselamatkan dan berburu bisa menjadi cerminan dari pelarian dari kemiskinan.

Kata Kunci: Anak - Anak, Kecemasan, Mekanisme Pertahanan

\section{A. Background}

Novel, as one kind of the studies, is a long fictional narrative that informs human's life experience in many different genres. In fictional literature, authors use many different types of characters to convey the actual purposes of the story.

As an imaginative work, novel can be the mirror of actual human life and it is immortal as what states by Sartre that novel is not life but they owe their power upon us, as upon himself as an infant, to be the fact that they somehow like life. The novel is a lie only as our quotation inventions are lies the power which goes to its making -the imagination- is a function of man's inescapable freedom. Novels, then, have beginning, ends, and potentially, even if the world has not ${ }^{1}$

Story about children is one of an interesting theme that always told by the authors on their works. It can be both entertaining and educating for the readers particularly the children. It improves time to time as well as the use of

\footnotetext{
${ }^{1}$ Frank Kermonde, The Sense Of An Ending; Studies In The Theory Of Fiction (London: Oxford University Press, 2000).
} 
literary works as one tool in studying language as Rahman states that children's literature is growing rapidly in line with the need to provide reading matter and entertainment the children. It indicates that the literary works nowadays have a special place as it can help children studying language and getting the moral message through the story. Children's literature is not read by the children, it also read by adults as the thing which can be entertaining and educating them about children and childhood in order to make adults be more understanding about children moreover about their psychology. ${ }^{2}$

Childhood is one phase in human life that is very important part which it can steer how people behave in their adult life. shows that according to Hurlock, childhood can be divided into two periods, those are early childhood (2-6 years old) and late childhood (6-12 years old). In this study the writer use the term of children to generalize the age of characters where the youngest is six years old and the oldest is 12 years old. ${ }^{3}$

This research aims to analyse the personalities of children on novel of William Golding and their psychological development by using the psychoanalysis theory as well as to find out the way those kids think and act out of usual in order to struggle in a very strange area for them who in real life they just need to play and live normally as children in their childhood. ${ }^{4}$

Lord of the Flies is novel by one of British author, William Golding who is the Nobel Prize-winning in his era through this novel. Written in 1954, William Golding made this novel as a tragic parody of the children's adventure story,

\footnotetext{
2 Fathu Rahman, "The Revival of Local Fairy Tales for Children Education," Theory and Practice in Language Studies 7, no. 5 (2017): 336-344, https://www.academypublication.com/ojs/index.php/tpls/article/view/tpls0705336344.

${ }^{3}$ Herlina, Bibliotherapy: Mengatasi Masalah Anak Dan Remaja Melalui Buku, 1st ed. (Bandung: Pustaka Cendekia Utama, 2013).

${ }^{4}$ Khamis Mohammad, "Understanding of Humanity A Study in: William Golding's Lord of the Flies Khamis Khalaf Mohammad --- Awfa Hussien Aldouri Journal of Tikrit University for the Humanities الإز ساذ ية ل ل لع لموم ت كريد ت جامعة مج لة ISSN: 18176798 Year: 2011 Volume: 18 Issue: 6 Pages" (March 17, 2008).
} 
which depicts humans in evil. He presents the reader with a chronology of events leading a group of young boys from hope to disaster as they strive to survive themselves from uncivilized, unattended, and isolated environments until got helping. 5

This novel shows some young English boys who are being evacuated from the nuclear war by flying to leave England forward a peaceful destiny. Unfortunately, their plan fell down on an island. All adults included the pilot die because of the crashed plane. One of them found the conch and it makes him elected as a leader by voting although he doesn't receive the votes from the members of a boys' choir who are led by the Jack Merridew. The conch later becomes an important stuff; to call the assembly and as a symbol of having a right to speak in meeting without interrupted by other boys except by the leader.

The main characters of this story are, Ralph and Jack. As an elected leader, Ralph emphasizes three main goals: having fun, surviving, and maintaining a smoke signal that could alert the passing ships to their presence on the island. Jack is the chief of the choir who is arrogant and asserts to be a chief since he assumes that he has more reasons to be the leader rather than Ralph. Besides, the other important character is Piggy who is depicted as a fat boy with specs and always feels as an outsider among the group but he is full of bright ideas which convey to Ralph as the one who is supposed as his closed-friend.

Lord of the Flies is an allegory to feature out two sides of human, kind and evil. For people are specially created to be a social being, move and grow in a civilized world with laws and commandments, there is a dark side within us that in certain circumstances or influence will reveal it and even defeat our good sense.

Every human being has been created with things that are different from

\footnotetext{
${ }^{5}$ Bernadus Hidaya Jamiah Solehati, "The Significance of the Conch in William Golding's Lord of Flies," Lexicon 6, no. 2 (2019): 156-163, https://jurnal.ugm.ac.id/lexicon/article/view/53150.
} 
one another. Humans need the space for self-expression, exchanging ideas, and organizing themselves into a purposed group. Because humans live in social structures where they need to prove themselves and live in structures where there must be battles in different characters.

Furthermore, human and society cannot be separated for they are related one another. Men try to make and show their identity in a particular society where they live through their feelings, thoughts, emotions, and abilities. When one identity meets another or others in a same society, there are two possibilities could be appeared; the identities can create happiness by accepting and understanding each other or it may be the conflict when psychologically the identities show their bad responses and the possibility to life well is difficult to be created.

Realizing the conditions above, novel as one of literary works may also explain the kinds of human conditions and it is considering as a fact in real world, Culler emphasizes that: A literary work-Hamlet, for instance-is characteristically the story of a fictional character: it presents itself as in some way exemplary (why else would you read it?), but it simultaneously declines to define the range or scope of that exemplary - hence the ease with which readers structure of literary works is such that it is easier to take them as telling us about "the human condition" in general than to specify what narrower categories they describe or illuminate. ${ }^{6}$

By knowing and appreciating literary works, people may recognize human life with all its complexities. In expressing the character of children in the novel Lord of the Flies, the author uses psychoanalysis, because it is used to analyse people's thoughts and the complexity of human thinking about internal

\footnotetext{
${ }^{6}$ Jonathan Culler, The Cambridge Companion to Oscar Wilde (Cambridge Companions to Literature), ed. Peter Raby (Cambridge University Press, 1997).
} 
and external emotional conflicts. ${ }^{7}$ It is to figure about the things which will happen with boys who are forced to live alone without adult supervision on a remote island for days, where they have different ambitions or what are the same, as well as different characters. The writer believes that the type of basic action (identity ambiguity) as one of the defence mechanisms acting in psychoanalysis and action logically creates conflict. Krapps supports that: This conflict, according to Freud, brings anxiety and serves as a signal to the ego that its survival may be in jeopardy. As the result, many ways of people behave or think toward unpleasant thoughts, feelings and behaviours. ${ }^{8}$

According to the statements above, the writer notes that defence mechanism is the beginning of ambiguities, where Krapp also emphasizes that the ego deals with the demands of reality, the urges of the id, and the perfectionist tendencies of the superego as best as it can. But when the anxiety becomes overwhelming, the ego must defend itself. ${ }^{9}$

As the reflection of statements above, the writer believes that every human being has his/her own defence mechanism as the protection of the condition around his/her as what told by the content of the literary works as the reflection of human's true-event. Furthermore, the writer attempts to analyse the characters and how that possible to be developed in a society influenced by the appearance of the defence mechanism as the unconscious accumulation of anxieties. As the contribution to social life, the writer took the depiction of the effort in decreasing the poverty in the novel.

Some related studies that took the novel Lord of the Flies and psycholinguistic as their object had been conducted by previous writers. The

\footnotetext{
${ }^{7}$ Muhammad Nasir, "Educational Values of the Dream and Reality Psychoanalysis In Â?]Sang Pemimpiâ?] (the Dreamer), a Novel by Andrea Hirata," Institut Agama Islam Negeri Imam Bonjol Padang Vol 22, No (2015).

${ }^{8} \mathrm{~K}$ M Krapp, Psychologists and Their Theories for Students, Gale virtual reference library (Thomson Gale, 2005), https://books.google.co.id/books?id=Tdn3oAEACAAJ.

${ }^{9}$ Ibid.
} 
writer presents them as follows.

The first study was conducted by Andri and Yenny through their article under the title Teori Kecemasan Berdasarkan Psikoanalisis Klasik dan Berbagai Mekanisme Pertahanan terhadap Kecemasan in Majalah Kedokteran Indonesia volume: 57. The journal explains about the relation between anxiety and defence mechanism. Anxiety comes from the unrelieved libido, then according Freud that the anxiety; reality anxiety, neurotic anxiety, and moral anxiety which are caused by the inside and outside factor where it makes the ego threatened and unconsciously results the defence mechanism. As the result, the journal states that the defence mechanism is born to overcome the anxiety, it indicates that the defence mechanisms to anxiety situation are; repression, reaction formation, projection, regression, rationalization, displacement, sublimation, isolation, undoing and intellectualization. ${ }^{10}$

The second is a study by Chairil Imran entitled The Portrait of Characters' Behaviour in Oscar Wilde "the Importance of Being Ernest." A defence mechanism based analysis. The aims of the study are to discuss the kind of defence mechanism performing by the characters in The Importance of Being Ernest in their respected positions and to reveal the implementation of characters' mechanisms in managing and solving the rising conflicts. The study resulted that the defence mechanism acts exist at every level of characters' unconsciousness. The writer shows that the most defence mechanisms perform by the characters are; denial, displacement, projection, reaction formation, regression and rationalization. Besides, despite there are three cores of conflicts in the play, but the writer found that those conflicts do not become the real conflict since some characters

\footnotetext{
${ }^{10}$ Yenny Dewi, Andri, "Teori Kecemasan Berdasarkan Psikoanalisis Klasik Dan Berbagai Mekanisme Pertahanan Terhadap Kecemasan," Majalah Kedokteran Indonesia 57, no. 7 (2007): 233, https://www.researchgate.net/profile/Andri_Andri/publication/210277782_Anxiety_Theory_Based _On_Classic_Psychoanalitic_and_Types_of_Defense_Mechanism_To_Anxiety/links/08fd487bf74e1f 5032ab8275/Anxiety-Theory-Based-On-Classic-Psychoanalitic-and-Types-of-Defense-MechanismTo-Anxiety.pdf.
} 
are able to overcome any related problems in it. ${ }^{11}$

The third is the study which has been written by Meuronen by the tittle Construction of Otherness in William Golding's Lord of the Flies. The study focussed on the process of how the boys divide into two hostile groups in Golding's novel, and why they become so violent with each other. The main research problem of that research is; how is Otherness constructed in Lord of the Flies? Furthermore, this study aims at answering how Golding describes the State of Nature in the novel as this affects the construction of Otherness. The results of this study are; 1) the otherness is constructed in Lord of the Flies on the way children end up the barbaric situation in the novel and how they try to become socialist, 2) Golding shows two representations of human; evilness and rationalism. It is depicted when they are separated into two different groups; Ralph's tribe and Jack's tribe. Jack is shown as the boy with strong tendency for violence and inhumanity. ${ }^{12}$

The fourth is Humanity Square One: From William Golding's Lord of the Flies to $A B C$ "s LOST by Iliadou, a research to the Department of American Literature and Culture, School of English, Faculty of Philosophy of Aristotle University of Thessaloniki. This project focuses on William Golding's Lord of the Flies and ABC"s LOST. The suppose of it is to examine these texts, both separately and in conjunction, in order to examine their approach on human nature, as well as the need to reestablish our connection with other people and, ultimately, with ourselves. The result that that can be read from the thesis is that the scenario of the lost castaways, marooned in a secluded, isolated place, trying to work together in order to survive, is favoured by the American audience since it functions as a projection of their own need to confront their fears and reconnect

\footnotetext{
${ }^{11}$ Oscar Wilde et al., "The Portrait as an Alive Character in The Picture of Dorian Gray" 4 (January 1, 2014): 2225-2484.

12 Johanna Meuronen, Construction of Otherness in William Golding's Lord of the Flies, 2013, https://www.semanticscholar.org/paper/Construction-of-otherness-in-William-Golding's-LordMeuronen/62bc7bc1f22995016bb33782c8c6579b5b4b1701\#paper-header.
} 
with everyone around them in order to make a step forward and evolve. ${ }^{13}$

The fifth study is the research by the tittle 'dialogism as Character Development": Psychoanalysis and Play in Siri Hustvedt's The Summer without Men and The Sorrows of an American" written by Nygard (2017). There are two focuses in this study that has chosen by the writer;

Psychoanalysis and play. This thesis shows dialogism as character development in psychoanalysis and play of Siri Hustvedt's novels The Summer without Men and The Sorrows of an American. The results shows the evidence that the I-You entity of dialogism enables character development in the main characters of the novels. Besides, it results that the elements of playfulness and play in and between novels, roles in psychoanalysis, mirroring and the relationship between conscious and unconscious, development of personality and reconstruction in psychoanalysis.

From those five studies above, the writer declined the different with the study she has conducted. The first research has done the study about how the otherness constructed in Golding's Lord of the Flies which it has the same source of data with the third research above with the focus on the humanity square from the novel that also the novel that was analysed by the writer. The second, the fourth, and the fifth previous studies use the theory of psychoanalysis in their research as well as the writer used in her study.

To make the different, the writer who also used the novel Lord of the Flies as the object of the research and used the psychoanalysis approach as the theory to help doing the research in order to find the possibility of characters' development in this novel, so beside tried to find the aspect of how the characters' personalities develop through her study, the writer also shows the exertion to eradicate poverty that shown in the novel through the attempts of

\footnotetext{
${ }^{13}$ Ibid.
} 
children to get them out from the uncivilized island as the contribution of literature's work for social life.

The data analysis in this study was conducted by using the descriptive qualitative method. Descriptive qualitative method often has the aim of description and writers may follow-up with examinations of why the observations exist and what the implications of the findings are.

In this study, the writer started the analysis on the structure of the novel the Lord of the Flies. Next, the writer further investigated the elements of selected problems derived from each structure to relate them with the data derived from any supporting external texts. Thus, in this section, the writer would draw the relation between the elements of literary works and any conception derived from supporting sources. Sorts of elements shown in the literary works (the characters, depiction of objects, the perception to anything) would later be connected to the concepts based on theoretical background that the writer used to analyse this study.

The writer collected the data which are indicated have the relation with the development of personalities by classifying the data based on the event in the novel and made them sequence in order to ease the data analysis. Furthermore, the writer detected the possibility of the personalities improvement through the dialogue of the characters and then analysed the data by using the theory of Sigmund Freud called psychoanalysis.

The writer found the basic personalities of the children that are told in the beginning of the story, and then the writer ordered the problems found in the novel. The finding problems are indicated as the reason of the personalities' development seen by the defence mechanisms that are performed by the characters. Defence mechanism is an unconscious reaction by human for being circumstances of the situation. As what the theory of psychoanalysis explains that when Ego, which works to balance the id and superego, is in thread in this 
case causing by the anxiety, anger, and uncomfortable condition, unconsciously it will show the defence mechanism as the reaction and it is indicated the development of personality.

\section{B. Discussion}

Lord of the Flies, the work of William Golding is Lord of the Flies is a 1954 novel by Nobel prize-winning English author William Golding. In this novel William Golding intended this novel as a tragic parody of children's adventure tales, illustrating humankind in evil nature. He presents the reader with a chronology of events leading a group of young boys from hope to disaster as they attempt to survive their uncivilized, unsupervised, isolated environment until rescued.

In the novel Lord of the Flies, the dominant characters are boys who are needed to be rescued from an Island where their plane crushed and the pilot was passed away leave them alone without adult guidance.

To analyse the personalities" development, the writer uses anxiety and defence mechanism theory by Sigmund Freud where both terms are correlate each other. Defence mechanism is the product of many anxieties as what Snowden states that defence mechanisms are initiated unconsciously when there are too many anxieties disturbing the ego. The anxieties have the potential to harm a person's mental health, make them vulnerable. Therefore, these defence mechanisms can be used as strategies to hide from anxiety. ${ }^{14}$

\section{Summary of Lord of the Flies}

Lord of the Flies explores the dark side of humanity, the savagery that underlies even the most civilized human beings. William Golding intended this

\footnotetext{
${ }^{14}$ Ruth Snowden, Freud: The Key Ideas (Hodder Education, 2010).
} 
novel as a tragic parody of children's adventure tales, illustrating humankind's intrinsic evil nature. He presents the reader with a chronology of events leading a group of young boys from hope to disaster as they attempt to survive their uncivilized, unsupervised, isolated environment until rescued.

In the midst of a nuclear war, a group of British boys find themselves stranded without adult supervision on a tropical island. The group is roughly divided into the "littluns," boys around the age of six, and the "biguns," who are between the ages of ten and twelve. Initially, the boys attempt to form a culture similar to the one they left behind. They elect a leader, Ralph, who, with the advice and support of Piggy (the intellectual of the group), strives to establish rules for housing and sanitation. Ralph also makes a signal fire the group's first priority, hoping that a passing ship will see the smoke signal and rescue them. A major challenge to Ralph's leadership is Jack, who also wants to lead. Jack commands a group of choirboys-turned-hunters who sacrifice the duty of tending the fire so that they can participate in the hunts. Jack draws the other boys slowly away from Ralph's influence because of their natural attraction to and inclination toward the adventurous hunting activities symbolizing violence and evil.The conflict between Jack and Ralph — and the forces of savagery and civilization that they represent — is exacerbated by the boys' literal fear of a mythical beast roaming the island. One night, an aerial battle occurs above the island, and a casualty of the battle floats down with his opened parachute, ultimately coming to rest on the mountaintop. Breezes occasionally inflate the parachute, making the body appear to sit up and then sink forward again. This sight panics the boys as they mistake the dead body for the beast they fear. In a reaction to this panic, Jack forms a splinter group that is eventually joined by all but a few of the boys. The boys who join Jack are enticed by the protection Jack's ferocity seems to provide, as well as by the prospect of playing the role of savages: putting on camouflaging face paint, hunting, and performing ritualistic 
tribal dances. Eventually, Jack's group actually slaughters a sow and, as an offering to the beast, puts the sow's head on a stick.

Of all the boys, only the mystic Simon has the courage to discover the true identity of the beast sighted on the mountain. After witnessing the death of the sow and the gift made of her head to the beast, Simon begins to hallucinate, and the staked sow's head becomes the Lord of the Flies.

Imparting to Simon what he has already suspected: The beast is not an animal on the loose but is hidden in each boy's psyche. Weakened by his horrific vision, Simon loses consciousness.

Recovering later that evening, he struggles to the mountaintop and finds that the beast is only a dead pilot/soldier. Attempting to bring the news to the other boys, he stumbles into the tribal frenzy of their dance. Perceiving him as the beast, the boys beat him to death.

Soon only three of the older boys, including Piggy, are still in Ralph's camp. Jack's group steals Piggy's glasses to start its cooking fires, leaving Ralph unable to maintain his signal fire. When Ralph and his small group approach Jack's tribe to request the return of the glasses, one of Jack's hunters releases a huge boulder on Piggy, killing him. The tribe captures the other two biguns prisoners, leaving Ralph on his own. 
The tribe undertakes a manhunt to track down and kill Ralph, and they start a fire to smoke him out of one of his hiding places, creating an islandwide forest fire. A passing ship sees the smoke from the fire, and a British naval officer arrives on the beach just in time to save Ralph from certain death at the hands of the schoolboys turned savages.

As all authors use their life and times as reference points in their works, William Golding drew heavily on the social-religious-cultural-military ethos of his times. Lord of the Flies is an allegorical microcosm of the world Golding knew and participated in. The island and the boys and many other objects and events in the work represent Golding's view of the world and humankind in general and some characteristics or values found in British culture specifically.

Significant personal life experiences shaped the author and therefore his work. Golding spent two years as a science student at Oxford University before he aborted his pursuit of science for a degree in English literature, his first step toward a rejection of the scientific rationalism espoused by his father. Having joined the British Royal Navy when World War II began, Golding was involved in the invasion of Normandy on D-Day. After his military experience, Golding was a schoolteacher and, for 15 years, immersed himself in reading the Greek classics because, according to him, "this is where the meat is." He felt that Greek drama had a great influence on his work; many scholars agree. 
As a synthesis of Golding's life experiences, Lord of the Flies investigates three key aspects of the human experience that form the basis of the the author wants to convey: (1) The desire for social and political order through parliaments, governments, and legislatures (represented by the platform and the conch). (2) The natural inclination toward evil and violence, manifested in every country's need for a military (represented by the choir-boys-turned-huntersturned-murderers and in the war going on in the world beyond the island); and (3) The belief in supernatural or divine intervention in human destiny (represented by the ceremonial dances and sacrifices intended to appease the "beast").

By juxtaposing the evil, aggressive nature of the degenerating boys with the proper reserve and civility of the British persona that their cultural background implies, Golding places the boys in a series of life experiences that lead some (like Jack) deeper into their depraved psyche, and some (like Ralph), who recognize the inclination toward evil in themselves, to an epiphany of selfdiscovery. Such an epiphany is the only hope for humankind to escape from itself.

\section{History of Lord of the Flies}

Golding wrote Lord of the Flies in 1954, less than a decade after World War II, when the world was in the midst of the Cold War. The atrocities of the Holocaust, the horrific effects of the atomic bomb, and the ominous threat of the Communist demon behind the Iron Curtain were all present in the minds of the western public and the author. This environment of fear combined with technology's rapid advances act as a backdrop to the island experiences: the shotdown plane, for example, and the boys' concern that the "Reds" might find them before the British do. 
Historically, in times of widespread socio-economic distress, the general public feels itself vulnerable and turns to the leader who exhibits the most strength or seems to offer the most protection. In Lord of the Flies, Jack and the hunters, who offer the luxury of meat and the comforts of a dictatorship, fill that role. In exchange for his protection, the other boys sacrifice any moral reservations they may have about his policies and enthusiastically persecute the boys who resist joining their tribe. These circumstances somewhat mirror Germany's economic suffering, which paved the way for the radical politics of Adolph Hitler's Nazism in the aftermath of World War I and in the worldwide depression of the 1930s.

Based upon his wartime experiences in the British Navy, Golding asserted that the unlimited brutality shown by the Nazis was a capacity not limited to Germans or indeed to any particular group. While the world was horrified by news of the Nazi death camps, Golding felt that none of the nations was too far from committing atrocities of the same magnitude. According to Golding, humankind's propensity toward evil and violence coupled with the "psychology of fear" motivates humanity to act in unconscionable ways. When the United States used the atomic bomb in Japan, more than 100,000 people were killed in three days by dropping two bombs. Overall, a total of 55 million people lost their lives in World

War II. Such catastrophic violence and loss of life was clearly not lost on Golding: An atomic war causes the boys' evacuation in Lord of the Flies, and the sign from the world of grownups that the boys so wish for turns out to be the body of a dead paratrooper, floating down from an aerial battle.

\section{Sociological/Ideological Concerns}

Such a fatalistic view of humanity directly conflicted with the rationalism on which Golding was raised. His father's rationalist optimism held 
that humankind can be perfected with enough effort, purged of aggressive or anti-social tendencies. Golding's view is much more pessimistic about humankind's true makeup; he perceived human nature as equal parts good and evil, permanently intertwined. Rather than looking to social reform to cure humanity of its cruelty, Golding felt that breakdown in the social order, such as occurs in Lord of the Flies, is directly traceable to moral meltdown at the individual's level.

Golding's representation of humanity's inherent evil is a treatment of the Judeo-Christian concept of original sin. When Lord of the Flieswas published, many critics were not impressed by it because Golding was not part of one of the contemporary literary movements, which concerned themselves not with theology or mysticism but with existential and sociological themes. Instead Golding was a 43-year-old schoolteacher with a wife and children addressing classic themes of good and evil.

As a schoolteacher, however, Golding experienced the reality of schoolboy behavior and tendencies, which provided him with valuable literary material. That reality was quite different from the picture painted in many children's adventure stories, such as R. M. Ballantyne's classic Victorian tale Coral Island. Coral Islandexemplified certain assumptions about English schoolboys and British culture that Golding knew to be false, such as the idea that British Christian children were naturally virtuous and innocent. Golding wrote Lord of the Flies as a solemn parody of Coral Island,relocating savagery from the external sources such as heathens and foreigners to residency in each individual's heart.

Another issue Golding addressed was the western world's post-war confidence in technology, another spin on the rationalist idea that human society can be perfected; rationalism's anti-mystical bent is a part of technology worship. Included in the scientific advances of the first half of the 
twentieth century was the field of psychiatry, which promised to explain emotional disturbances in a logical way - a technology of the mind. Golding wove in references to technology's influence in Lord of the Flies through " Piggy, who asserts that psychiatry can explain away their fears and that ghosts can't exist because if they did then television and streetlights wouldn't work. While Golding's novel does not prove the existence of ghosts, it does provide a complex commentary on the underlying fears and true demons found in humanity.

\section{Characters' Personalities Development}

Basically, the feeling of anxiety has surrounded the characters since the beginning of story by the crushing plane makes them fall in a deserted area and it grows by time and by things happens and create many anxieties such as the beast and snake thing, the issue about ghost, the fire which just resulted flames, and the biggest problem is when Jack and his followers decide to leave the groups where Ralph is the chief and make a new tribe.

Then the other problems appear. The writer takes the data to show the changes of the characters and the cause of it. The defence mechanism found from the novel are; (1) projection, (2) reaction formation, (3) aggression, (4) regression, (5) rationalization, (6) sublimation, (7) stereotype.

\section{Poverty Alleviation}

Poverty is the condition where people's basic needs for food, clothing, and shelter are not being met. Poverty is generally of two types: (1) Absolute poverty is synonymous with destitution and occurs when people cannot obtain adequate resources (measured in terms of calories or nutrition) to support a minimum level of physical health. Absolute poverty means about the same everywhere, and can be eradicated as demonstrated by some countries. (2) 
Relative poverty occurs when people do not enjoy a certain minimum level of living standards as determined by a government (and enjoyed by the bulk of the population) that vary from country to country, sometimes within the same country.

The writer takes the pure poverty to correlate with the condition of the children in the novel; they are in crisis where they have lack of shelter and most of the shelters they make are rotten, they have fruits around them but the nutrition is not fulfilled just by the fruit. Furthermore, they sometimes get stomached caused of the food they eat. They also have no clothes except what they are wearing since they are in the island.

\section{Conclusion}

Lord of the Flies is an allegory novel which interprets two sides of human being. There always be kind and evil. The novel shows how the boys struggle due to get themselves safe and fulfil they need while waiting for the rescue. Meanwhile, their personalities change through the circumstance which appears anxiety, anger, and even the death of two boys.

The development of the children's character personalities caused of the anxiety they feel by being in the barren area and result the appearance of some problems; (1) the snake and the beast, (2) the fire (3) fire versus meat, and those three problems caused the appearance of (4) the new tribe. To encounter the problems, the characters perform defence mechanisms which are; (1) projection, (2) reaction formation, (3) aggression, (4) regression, (5) rationalization, (6) sublimation, (7) stereotype. Defence mechanism is not the personality but it reflects the personality development.

In relation with the effort of being rescued, the children characters in novel show the exertion related to the poverty eradication which can be depicted by the efforts of the children do in their struggle to be rescued. They 
are (1) making shelter as a place of protection and to take a rest, and (2) hunting to get meat to fulfil the need of healthy food and the last (3) being rescued by making fire in order to save them from the crisis which is the last hope for the children.

\section{DAFTAR PUSTAKA}

Andri, Yenny Dewi. “Teori Kecemasan Berdasarkan Psikoanalisis Klasik Dan Berbagai Mekanisme Pertahanan Terhadap Kecemasan.” Majalab Kedokteran Indonesia 57, no. 7 (2007): 233.

https://www.researchgate.net/profile/Andri_Andri/publication/21027778 2_Anxiety_Theory_Based_On_Classic_Psychoanalitic_and_Types_of_Defe nse_Mechanism_To_Anxiety/links/08fd487bf74e1f5032ab8275/AnxietyTheory-Based-On-Classic-Psychoanalitic-and-Types-of-Defe.

Culler, Jonathan. The Cambridge Companion to Oscar Wilde (Cambridge Companions to Literature). Edited by Peter Raby. Cambridge University Press, 1997.

Herlina. Bibliotherapy: Mengatasi Masalah Anak Dan Remaja Melalui Buku. 1 st ed. Bandung: Pustaka Cendekia Utama, 2013.

Jamiah Solehati, Bernadus Hidaya. "The Significance of the Conch in William Golding’s Lord of Flies.” Lexicon 6, no. 2 (2019): 156-163. https://jurnal.ugm.ac.id/lexicon/article/view/53150.

Kermonde, Frank. The Sense Of An Ending; Studies In The Theory Of Fiction.

London: Oxford University Press, 2000.

Krapp, K M. Psychologists and Their Theories for Students. Gale virtual reference library. Thomson Gale, 2005. https://books.google.co.id/books?id=Tdn3oAEACAAJ.

Meuronen, Johanna. Construction of Otherness in William Golding's Lord of the Flies, 2013. https://www.semanticscholar.org/paper/Construction-of-othernessin-William-Golding's-Lord- 
Meuronen/62bc7bc1f22995016bb33782c8c6579b5b4b1701\#paper-header. Mohammad, Khamis. "Understanding of Humanity A Study in: William Golding's Lord of the Flies Khamis Khalaf Mohammad --- Awfa Hussien ت كري ت جامعة مج لة Aldouri Journal of Tikrit University for the Humanities الإن ساذ ية لـ لـع لوم ISSN: 18176798 Year: 2011 Volume: 18 Issue: 6 Pages” (March 17, 2008).

Nasir, Muhammad. "Educational Values of the Dream and Reality Psychoanalysis In $\hat{A} \square \square$ Sang Pemimpiâ $\square \square$ (the Dreamer), a Novel by Andrea Hirata.” Institut Agama Islam Negeri Imam Bonjol Padang Vol 22, No (2015).

Rahman, Fathu. "The Revival of Local Fairy Tales for Children Education." Theory and Practice in Language Studies 7, no. 5 (2017): 336-344. https://www.academypublication.com/ojs/index.php/tpls/article/view/tpl s0705336344.

Snowden, Ruth. Freud: The Key Ideas. Hodder Education, 2010.

Wilde, Oscar, Ekbal Al-Jabbari, Ala Eddin Jarab, and Sadeq Jrab. "The Portrait as an Alive Character in The Picture of Dorian Gray" 4 (January 1, 2014): $2225-2484$. 
|Aisyiyah Muallim, The Development of Children's Personalities In William .. 